\title{
GEOLOGY AND MAMMALIAN PALEONTOLOGY OF \\ NEOGENE STRATA IN JACKSON HOLE, WYOMING
}

\author{
Anthony D. Barnosky \\ Department of Geological Sciences \\ University of Washington
}

\section{Objectives}

Stratigraphic distributions and geographic variation of small mammals, principally Miocene in age, are being studied. The aim is to help construct a biostratigraphic framework that covers the north-central Rockies, as well as to clarify the importance of large mountain ranges as biogeographic barriers for small mammals. Principal goals of the 1981 field season, which was part of a longer-term project (Barnosky, 1980), included detailed measurement of stratigraphic sections and collection of Neogene mammals in Jackson Hole, Wyoming. A secondary goal was field study of Tertiary sediments in nearby intermontane basins in order to understand the regional character of sedimentation.

\section{Methods}

Sections of the Miocene Colter Formation along Pilgrim Creek, Two Ocean Lake, Cunningham Hill, and Shadow Mountain were measured in detail. Brunton-and-tape and Jacob's staff methods were used. For each of the 12 sections, the thickness of each stratum to the nearest decimeter, rock type, grain size, sphericity, cementation, composition, color, roundness, sorting, bedding, sedimentary structures, fossils, orientation of paleocurrent indicators, and strike and dip were determined. Approximately 200 beds were sampled for potential radiometric dating and/ or further laboratory analyses.

A taphonomic excavation of the Dipoides Quarry, in the Teewinot Formation along Kelly Road, was undertaken. The sedimentary sequence was analyzed on a centimeter-by-centimeter basis, and the orientation of every fossil was mapped into a 5-meter square grid. After quarrying, matrix was bagged and broken down for screen washing to recover microfossils.

Approximately $700 \mathrm{~kg}$ of sediment from the Shooting Iron Formation, which overlies the Teewinot on the National Elk Refuge, was screened for microfossils.

Outside of Jackson Hole, sections were measured and described at Split Rock, Wyoming, Lemhi Valley, Idaho, and Chalk Cliffs, Deep River, Canyon Ferry, Anceney, Flint Creek, Tavenner Ranch, Deer Lodge and Blacktail 
Deer Creek, Montana.

\section{Results}

From the more than 4000 metres of section measured in Jackson Hole, it appears that two hitherto unrecognized faults cause the Colter Formation to be partially duplicated in outcrop. Evidence such as slickensides, highly fractured and crumbly rock, anomolous strikes and dips, and repetition of characteristic units suggests that faults trending NNE to SSW extend across the upper reaches of the East Fork of Pilgrim Creek, and along the westernmost drainage into the north side of Two ocean Lake. The bottom third of the Colter Formation consists mostly of tuffs and tuffaceous sandstones, the middle portion of largely pyroclastic debris (apparently not reworked), and the upper portion of fluviatile reworked volcanixlastics. From about 600 paleocurrent indicators, it appears that the currents that deposited these sediments were from the northwest and west. The regional comparisons, based on at least 4000 metres of section measured outside of Jackson Hole, show that the Colter sediments resemble others of similar age in the northcentral Rockies in being shardy and tuffaceous. However, the Colter Formation differs from nearly all the others in being either much coarser, richer in glass shards or both.

The taphonomic data from the Dipoides Quarry has yet to be interpreted, but several hundred specimens of Dipoides (a beaver), Microtoscoptes disjunctus (a vole), Peromyscus (mouse), and Hesperosorex (shrew) have been collected along with bones of reptiles, amphibians, and fish. Invertebrates include molluscs and ostracodes, and the fauna is associated with fossil grasses, rushes or sedges. All fossils come from a stratigraphic interval of less than $30 \mathrm{~cm}$.

Fifty fossil teeth were recovered from the Shooting Iron Formation. Preliminary identifications suggest that an advanced species of Pliopotamys (a muskrat) and two voles, probably Ophyomys and Pliophenacomys, were present.

\section{Conclusions}

The Colter Formation is in part fault repeated, with a true stratigraphic thickness of about 1500 metres. Although still representing one of the thickest Miocene sections in the United States, it is about 600 metres less thick than previously thought (Love, 1956). The formation is partially duplicated by two faults, which cut it along East Pilgrim Creek and Two Ocean Lake. In both cases the eastern block is downthrown. This knowledge will allow fossils from the Colter Formation to be placed in the proper stratigraphic sequence.

The coarser nature of the Colter and predominance of pyroclastic rocks indicate that Jackson Hole may have been closer to a source for Miocene 
volcanism than the other intermontane sediments examined. Judging from paleocurrents, this source was to the west of Jackson Hole, possibly not far from the modern Tetons.

The fossil assemblage at Kelly Road suggests deposition near the shore of a lake, and probably over a very short interval of time. The fossil will provide a basis for analyzing the population structure of extinct voles and beavers.

Sediments of the Shooting Iron Formation are late Pliocene in age, as suggested by the evolutionary stage of Pliopotamys. The muskrat is more advanced in development of dentine tracts than those from Hagerman or Sandpoint, but less advanced than those from Grandview in Idaho. The other microtines have yet to be examined in detail.

\section{Literature Cited}

Barnosky, A. D. 1980. Biostratigraphic and Biogeographic Implications of Miocene Mammals from Jackson Hole, Wyoming. University of Wyoming-National Park Service Research Center Fourth Annual Report: 24-27.

Love, J. D. 1956. New Formation Names, Jackson Hole, WY. Bull. Amer. Assoc. Pet. Geol. 40: 1899-1914.

\section{Acknowledgements}

I thank Kenneth Diem for providing space at the UW-NPS Research Center, and Bob Wood, John Wilbrecht, and Kevin Ryan for permission to work in Grand Teton National Park and the National Elk Refuge. The work was in part funded by the Geological Society of America, Sigma Xi, and the Corporation Fund of the Department of Geological Sciences, University of Washington. 